\section{APSA/JPSA Exchange Reaches 7th Year}

In a continuing effort to increase interaction between APSA members and Japanese political scientists, the APSA invited two members of the Japanese Political Science Association to participate in the 1996 Annual Meeting in San Francisco. Fumio Iida of Kobe University, presented a paper entitled "Liberalism in a Communal Society: In Search of Political Equality in PostWar Japan," and Ikuo Kabishima, from the University of Tsukuba, offered "Political Changes and Shifts in Japanese Voters' Attitudes." The APSA was also happy to welcome JPSA President Takeshi Sasaki, University of Tokyo, and Aiji Tanaka of Aoyama Gakuin University.

In early October, APSA members Herb Weisberg, Ohio State University and Clyde Wilcox, Georgetown University traveled to Sapparo, Japan at the invitation of the JPSA as APSA representatives to the 1996 JPSA meetings.

Since 1980 the APSA and JPSA have exchanged delegations to the annual meeting of each, helping en- hance the exchange of research and methods, and bridge the distance between colleagues.

\section{Bunche Fellows Attend Annual Meeting}

\section{Tharius D. Sumter, Olgethorpe University}

For graduating students facing the most pivotal decisions of their undergraduate careers, information is an invaluable resource. When this year's Ralph Bunche fellows attended APSA's Annual Meeting, they used the four day experience as a means of gathering even more facts and perspectives on graduate school and the field of political science.

Six of the ten Ralph Bunche fellows converged on San Francisco for an eagerly awaited reunion and the chance to gain an insider's view of the profession. Like the Ralph Bunche Summer Institute, the Annual Meeting was a unique opportunity for an undergraduate. However, in a way the Institute could not, the Annual Meeting exposed the fellows to the community of scholars who shape political science.

At the Annual Meeting the fellows made use of a number of sources unavailable in campus libraries. The Panel Paper Room placed the latest literature in the field within arm's reach. The research of several featured panelists will aid several of the fellows in completing their theses.

Bunche fellows met face-to-face with authors they have studied in the classroom. One highlight was the "Breakfast With Champions" where noted professionals like Lucius Barker (also a speaker at the Institute) and Richard Fenno discussed their careers and offered suggestions for research and graduate school study. Such mentoring discussions proved both enlightening and surprisingly entertaining.

The fellows, all rising seniors, also benefitted from contact with students currently enrolled in graduate schools who offered advice about preparing for graduate school mentally and financially.

Even in the midst of several preplanned receptions and panel sessions, the fellows found time to

\title{
CONTRIBUTORS TO ASPA AWARDS AND PROGRAMS
}

\author{
EDWARD ARTINIAN \\ SETH B. BENJAMIN \\ HENRY BRADY \\ WILLIAM CORLETT \\ CORNELIUS $P$. COTTER \\ MATTHEW DOPPKE \\ CYNTHIA H. ENLOE \\ LEON EPSTEIN \\ HENRY C. Galant \\ JOHN P. HARROD \\ KEN HEATH \\ PAUL S. HERRNSON \\ KIM HILDRED
}

\author{
ANNE HILDRETH \\ LOCH K. JOHNSON \\ STANLEY KELLEY, JR. \\ ANTHONY KING \\ PAUL F. KROMER \\ ROBERT E. LANE \\ ROBERT LORISH \\ KAREN M. MCCURDY \\ ROBERT J. MUNDT \\ GRADY H. NUNN \\ Dianne Pinderhughes \\ Ross R. RICE \\ BETH S. SchapIRo
}

\author{
H.P. SECHER \\ William C. SPRagens \\ JAMES L. SUNDQUIST \\ Ross B. TALBOT \\ JAMES A. THURBER \\ SEAN B. TIPTON \\ OLIVER WALTER \\ SUSAN WELCH \\ ANDREAS WESSERLE \\ JANET L. WOMACK \\ THANK YOU!!
}

